acute type A aortic dissection. J Thorac Cardiovasc Surg. 2021;161: 2017-26.e2.

2. Rosenblum JM, Leshnower BG, Moon RC, Lasanajak Y, Binongo J, McPherson L, et al. Durability and safety of David V valve-sparing root replacement in acute type A aortic dissection. J Thorac Cardiovasc Surg. 2019;157:14-23.e1.
3. Beckmann E, Martens A, Pertz J, Kaufeld T, Umminger J, Hanke JS, et al. Valvesparing David I procedure in acute aortic type A dissection: a 20-year experience with more than 100 patients. Eur J Cardiothorac Surg. 2017;52:319-24.

4. David TE. What to do when the acute type A aortic dissection involves the aortic sinuses. J Thorac Cardiovasc Surg. 2018;156:2083.
See Article page 2017.

\section{Commentary: Just because we can, should we do it?}

\author{
Hans-Joachim Schäfers, MD
}

Acute aortic dissection type A remains a deadly disease and a challenge to the surgeon. The initial 24 hours carry the greatest mortality, mostly due to pericardial tamponade. ${ }^{1,2}$ The primary goal of treatment is survival of the patient by treating or preventing pericardial tamponade. ${ }^{1,2}$ Replacement of the proximal aorta is and remains the mainstay of treatment. It is commonly performed as soon as the diagnosis is made, not infrequently at odd hours with unexperienced teams. Postoperative mortality is related to the preoperative presentation of the patient, with tamponade and severity of malperfusion being important determinants. ${ }^{2,3}$

Stability of the repair is second in priority. Tubular ascending replacement achieves long-term root stability in most instances. ${ }^{4,5}$ Only certain scenarios require more aggressive root surgery, ie, root replacement. ${ }^{4}$ This is definitely beneficial in connective tissue disease and may be considered for other scenarios, such as pre-existent root dilatation. ${ }^{4,6}$ Otherwise, there is no evidence that a more aggressive use of root replacement results in an advantage to the patient.

In the past 2 decades, valve-preserving root replacement has become an increasingly practiced approach also in acute dissection. ${ }^{4}$ In this setting, its increased complexity has to be carefully weighed against the advantage of avoiding

From the Department of Thoracic and Cardiovascular Surgery, Saarland University Medical Center, Homburg/Saar, Germany.

Disclosures: Author has nothing to disclose with regard to commercial support.

Received for publication Nov 11, 2019; accepted for publication Nov 12, 2019; available ahead of print Nov 20, 2019.

Address for reprints: Hans-Joachim Schäfers, MD, Department of Thoracic and Cardiovascular Surgery, Saarland University Medical Center, Homburg/Saar, Germany (E-mail: h-j.schaefers@uks.eu).

J Thorac Cardiovasc Surg 2021;161:2028-9

0022-5223/\$36.00

Copyright (c) 2019 by The American Association for Thoracic Surgery

https://doi.org/10.1016/j.jtcvs.2019.11.005
Check for updates

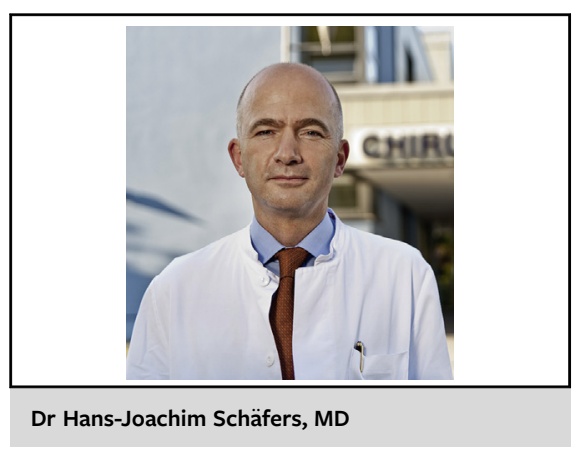

CENTRAL MESSAGE

In type A dissection, both valvepreserving root replacement and aggressive arch surgery may be performed in selected patients. The benefit of this approach still has to be defined.

anticoagulation. Similar considerations apply to the management of the arch. There has been discussion in favor of more aggressive arch surgery to minimize the probability of distal dilatation and subsequent surgery. In the majority of instances, partial arch replacement will suffice. ${ }^{1-4}$

In the current paper, ${ }^{7}$ the authors have combined valvepreserving root replacement and aggressive arch replacement; they achieved a low operative mortality. Comparing aortic valve reimplantation and the Bentall operation, they found no difference between the 2 strategies. They conclude that aggressive root and arch replacement can be performed safely. ${ }^{7}$ This is in contrast to previous findings that the duration of cerebral perfusion and circulatory arrest are important determinants of mortality. ${ }^{3,8}$

Do the positive results of this paper imply that the results and approach can be generalized? Common sense indicates that surgical aggressiveness does not always provide a benefit to the patient. The risk profile of the patients in the paper may differ from that seen in standard practice. The 2 most important risk indicators, ie, time from pain 
onset to surgery and details of preoperative malperfusion, are not specified. ${ }^{7}$ It seems that the cohort was a very selected one; through longer time after onset of dissection, possibly only the most stable were operated upon. In addition, all analyzed procedures were performed by the most experienced surgeons.

The conclusions of the paper have to be seen in the light of its limitations. More aggressive surgery may be performed in selected circumstances, but that does not make it safe as a general principle. For the majority of patients and surgeons, the more conservative surgical principles remain the standard until clearer evidence is available. In the absence of evidence, common sense is not the worst alternative.

\section{References}

1. Fann JI, Smith JA, Miller DC, Mitchell RS, Moore KA, Grunkemeier G, et al. Surgical management of aortic dissection during a 30-year period. Circulation. 1995; 92(9 suppl):II113-21.
2. Chiu P, Miller DC. Evolution of surgical therapy for Stanford acute type A aortic dissection. Ann Cardiothorac Surg. 2016;5:275-95.

3. Easo J, Weigang E, Hölzl PP, Horst M, Hoffmann I, Blettner M, et al. GERAADA study group. Influence of operative strategy for the aortic arch in DeBakey type aortic dissection: analysis of the German registry for acute aortic dissection type A. J Thorac Cardiovasc Surg. 2012;144:617-23.

4. Kunihara T, Neumann N, Kriechbaum SD, Aicher D, Schäfers HJ. Aortic root remodeling leads to good valve stability in acute aortic dissection and preexistent root dilatation. J Thorac Cardiovasc Surg. 2016;152:430-6.

5. Westaby S, Saito S, Katsumata T. Acute type A dissection: conservative methods provide consistently low mortality. Ann Thorac Surg. 2002;73:707-13.

6. Hiratzka LF, Bakris GL, Beckman JA, Bersin RM, Carr VF, Casey DE Jr, et al. A Report of the American College of Cardiology Foundation/American Heart Association task force on practice guidelines, American Association for Thoracic Surgery, American College of Radiology, American Stroke Association, Society of Cardiovascular Anesthesiologists, Society for Cardiovascular Angiography and Interventions, Society of Interventional Radiology, Society of Thoracic Surgeons, and Society for Vascular Medicine. J Am Coll Cardiol. 2010;55:e27-129.

7. Jun L, Yiping S, Tianyu Z, Yongshi W, Yongxin S, Hao L, et al. David reimplantation with simultaneous total arch replacement and stented elephant trunk for acute type A aortic dissection. J Thorac Cardiovasc Surg. 2021;161:2017-26.e2.

8. Sievers HH, Richardt D, Diwoky M, Auer C, Bucsky B, Nasseri B, et al. Survival and reoperation after valve-sparing root replacement and root repair in acute type A dissection. J Thorac Cardiovasc Surg. 2018;156:2076-82. 